\title{
Height at the withers estimation in the horses based on the internal dimension of cranial cavity
}

\author{
A. Chrószcz, M. Janeczek, E. Pasicka, J. Klećkowska-Nawrot \\ Division of Animal Anatomy, Department of Biostructure and Animal Physiology, Faculty of Veterinary Medicine, \\ Wroclaw University of Environmental and Life Sciences, Wroclaw, Poland
}

[Received 1 October 2013; Accepted 5 November 2013]

\begin{abstract}
The investigations were carried out on 17 modern half-breed horse skulls and their metacarpal and metatarsal bones. The basal length (BL), total length ( $T L)$, internal cranial cavity dimension and maximal length of metacarpus and metatarsus and maximal lateral length of metacarpus and metatarsus were measured according to Kiesewalter and von den Driesch. During height at the withers estimation, the Kiesewaler and Vitt methods were used. The Wyrost and Kucharczyk mathematical formula was modified for height at the withers calculation $\left(H_{\text {estmd }}=1.016 \times D\right)$ in horses. All height at the withers estimation methods were statistically analysed and compared. The analysis of variance ANOVA proved the lack of significant difference between the investigated values. The results achieved using Wyrost and Kucharczyk modified method are strongly comparable to Kiesewalter methods results computed using the metacarpal and metatarsal bones measurements. The height at the withers calculated on the basis of TL slightly differs from 2 above-mentioned methods. The BL Vitt's method was the least exact. (Folia Morphol 2014; 73, 2: 143-148)
\end{abstract}

Key words: craniometry, shoulder height, horses, statistical analysis

\section{INTRODUCTION}

Height at the withers (withers height) is an important phenotypical parameter in domestic animals [30] and may be used for selection and performance, especially of the horses. Horse performance in history allowed for the assumption that large animals would have been used in cavalry troops and therefore the withers height had significant influence on horse breeding $[15,16,29]$. Withers height estimation is an important indicator in archaeozoological investigation [1, 3-5, 7-9, 11-14, 17, 21, 24-26, 28, 31-35]. Osteometric calculations of withers height in animals (horses, dogs, pigs, cattle and deer) remain the most common method [3-5, 11-14, 28, 31, 35]. Similar methods have been used and modified in anthropology [27]. In archaeozoology, Koundel- ka [21] introduced the first method of the withers height calculation for the horses' remains. Moreover, Kiesewalter's and Vitt's method of the withers height estimation in horses is used in archaezoology $[2,6,9$, $23,34]$. All possible methods are estimations only. For instance, the method used by Vitt indicates only the range of withers height values (Table 1 ). Both methods are not sufficient because of remaining animal bone condition. The majority of animal artifacts is often strongly fragmented, thus the long bones measurements cannot be used. Sometimes the animal skull or part of it (neurocranium) still remains intact and the internal dimension of cranial cavity (EB) measurement is accessible [5, 35]. The EB is defined as the distance between the most rostral point of crista galli (ethmoideum) and the most ventral point of foramen 
Table 1. Shoulder height in horses estimated using various methods [cm]

\begin{tabular}{lccccccc}
\hline Horse number & Kies. LMc & Kies. LMt & Kies. TL & EB & Vitt Mc & Vitt Mt & Vitt BL \\
\hline 1 & 170.5 & 166.2 & 182.25 & 173.2 & $160-168$ & $160-168$ & $160-168$ \\
2 & 175.85 & 169.5 & 159.84 & 173.6 & $<168$ & $<168$ & $160-168$ \\
3 & 168.0 & 172.0 & 150.12 & 165.22 & $160-168$ & $160-168$ & $136-144$ \\
4 & 156.2 & 151.7 & 142.29 & 161.3 & $144-152$ & $152-160$ & $136-144$ \\
5 & 150.2 & 149.2 & 140.9 & 154.4 & $128-136$ & $128-136$ & $128-136$ \\
6 & 131.7 & 131.5 & 132.84 & 137.9 & $136-144$ & $136-144$ & $136-144$ \\
7 & 141.1 & 140.2 & 142.8 & 142.57 & $136-144$ & $136-144$ & $136-144$ \\
8 & 144.5 & 142.1 & 141.7 & 145.5 & $144-152$ & $144-152$ & $136-144$ \\
9 & 165.2 & 163.4 & 160.2 & 165.3 & $160-168$ & $160-168$ & $152-160$ \\
10 & 167.5 & 162.4 & 160.2 & 166.3 & $160-168$ & $160-168$ & $160-168$ \\
11 & 170.1 & 169.2 & 164.2 & 168.6 & $<168$ & $<168$ & $160-168$ \\
12 & 155.4 & 153.2 & 148.3 & 153.1 & $144-152$ & $144-152$ & $136-144$ \\
13 & 149.6 & 148.2 & 142.5 & 150.8 & $136-144$ & $136-144$ & $136-144$ \\
14 & 157.3 & 153.2 & 145.3 & 159.2 & $136-144$ & $144-152$ & $136-144$ \\
15 & 167.2 & 169.5 & 163.1 & 170.2 & $160-168$ & $160-168$ & $152-160$ \\
16 & 154.2 & 153.7 & 145.3 & 155.1 & $144-152$ & $136-144$ & $136-144$ \\
17 & 162.3 & 162.3 & 157.2 & 153.2 & $160-168$ & $160-168$ & $152-160$ \\
Mean value & 158.1 & 156.3 & 151.7 & 158.6 & - & - & - \\
Standard deviation & 11.9 & 11.8 & 12.2 & 10.7 & - & - & - \\
\hline
\end{tabular}

Kies. LMc — withers height estimation method based on lateral metacarpal measurement; Kies. LMt — withers height estimation method based on lateral metatarsal measurement; Kies. TL — withers height estimation method based on total length measurement; EB — withers height estimation method based on internal dimension of cranial cavity measurement; Vitt Mc — withers height estimation based on metacarpal measurement; Vitt Mt — withers height estimation based on metatarsal measurement; Vitt BL — withers height estimation based on basal length measurement

magnum (basion) [5, 7, 35]. Exact measurement points indicates Figure 1. Wyrost and Kucharczyk [34] designed a new mathematical formula for withers height estimation in dogs, using the EB. This method is accurate in brachycephalic, dolichocephalic and mesaticephalic dogs [5]. Wustinger at al. [33] successfully modified and used the Wyrost and Kucharczyk's formula in roe deer (Capreolus capreolus) withers height estimation based on the EB. These authors demonstrated clearly the possible use of Wyrost and Kucharczyk's formula in wild-living animals' archaeozoological investigations. In our work, the Wyrost and Kucharczyk's mathematical formula of withers height estimation was modified for use in horses. The modified formula efficiency and its accuracy in horse's withers height calculation were proved to be accurate.

\section{MATERIALS AND METHODS}

The investigation was carried out on 17 modern saddle type half-breed horse skulls (thoroughbred $\times$ $\times$ Wielkopolski breed) and their metacarpal and metatarsal bones, both right and left. This material

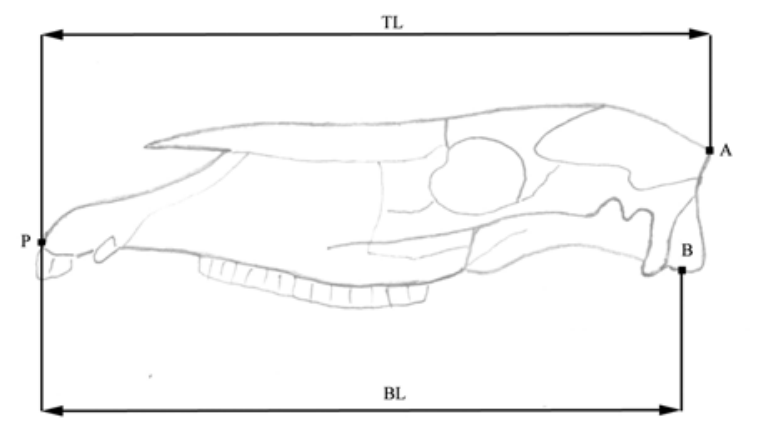

Figure 1. Craniometric measurements used in height at withers estimations; P — prosthion; B - basion; A - acrocranion; $\mathrm{TL}$ - total length of the skull; $\mathrm{BL}$ — basal length of the skull.

came from comparative collection of Department of Biostructure and Animal Physiology, Faculty of Veterinary Medicine, Environmental and Life Sciences University in Wroclaw and Department of Anatomy, Faculty of Veterinary Medicine, University of Warmia and Mazury in Olsztyn. The morphometric investigations do not include the live horses. The basal length of skull (BL, prosthion-basion), total length of skull (TL, prosthion-acrocranion) (Fig. 1), and EB 


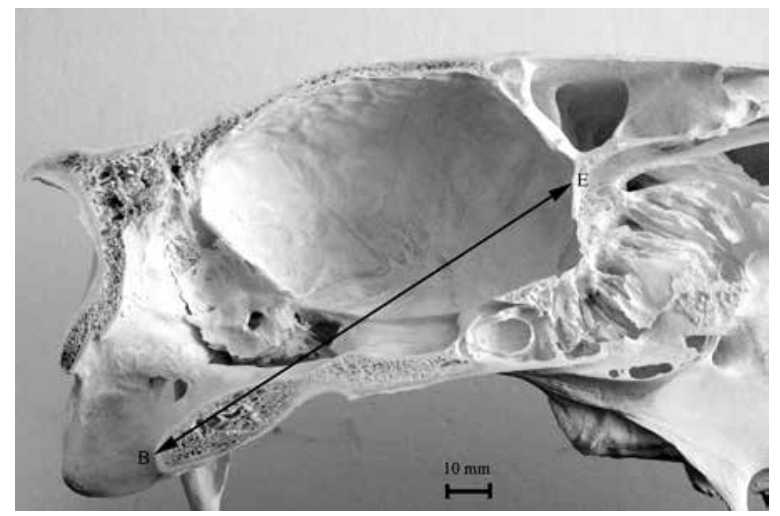

Figure 2. Craniometric measurements used in height at withers estimations; $\mathrm{E}$ - ethmoideum - the most rostral point of the crista galli in the median plane of the skull; B - basion.

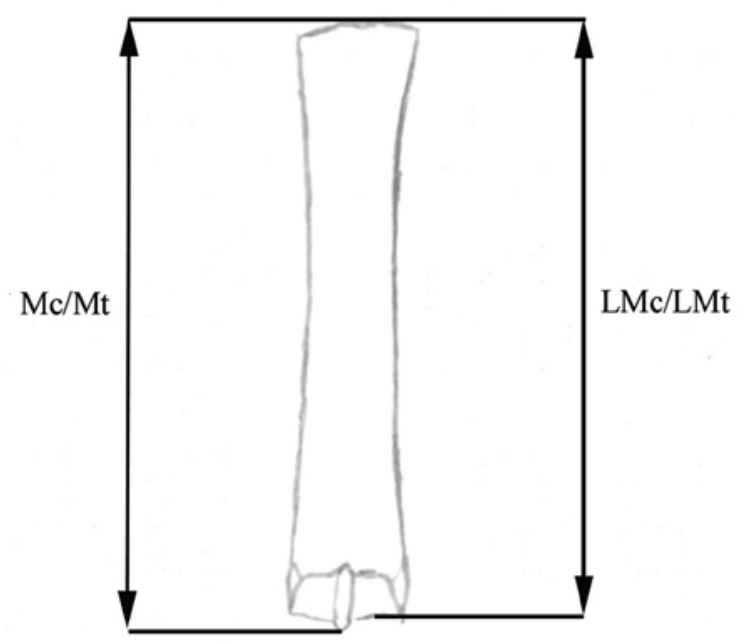

Figure 3. Osteometric measurements used in height at withers estimations; $\mathrm{Mc} / \mathrm{Mt}$ - maximal length of the metacarpal/ /metatarsal bone; LMc/LMt - maximal lateral length of the metacarpal/metatarsal bone.

(ethmoideum-basion) (Fig. 2) were measured according to the craniometrical points introduced by von den Driesch [5, 7, 35].

Maximal length of the metacarpal bone (Mc) and metatarsal bone (Mt) and maximal lateral length of the metacarpal bone (LMc) and metatarsal bone (LMt) according to Kiesewalter were measured [7]:

- maximal length of the $3^{\text {rd }}$ metacarpal bone and the $3^{\text {rd }}$ metatarsal bone (Mc/Mt) (Fig. 3);

- maximal lateral length of the $3^{\text {rd }}$ metacarpal bone and the $3^{\text {rd }}$ metatarsal bone (LMc/LMt) according to Kiesewalter (Fig. 3).

The withers height estimation methods:

- Kiesewalter's method is based on LMc, LMt and TL measurements; the osteometric results should be multiplied by 6.41 (LMc), 5.33 (LMt) and 2.7 (TL) as a multiplication factors;

- Vitt's method is based on Mc, Mt and BL measurements; the osteometric results should be compared with the values introduced by Vitt in order to estimate the range value of withers height;

- Wyrost and Kucharczyk's method is based on the EB measurement; the EB (D) is the distance between ethmoideum-basion (Fig. 2); the osteometric results should be computed using the modified Wyrost and Kucharczyk's mathematical formula: $H_{\text {estmd }}=1.016 \times D$, where $H_{\text {estmd }}$ is the estimated value of withers height, and $D$ is the internal dimension of cranial cavity [35].

The withers height was estimated according to Kiesewaler's and Vitt's methods. Next, the results were compared with withers height calculations achieved according to modified Wyrost and Kucharczyk's mathematical formula. Statistical analysis consisted of 4 parts. The $1^{\text {st }}$ part (descriptive statistics) consisted in the mean value, median, standard deviation (SD), maximum, minimum, Kolmogorov-Smirnov test (k-s test) and statistical significance estimation. The $2^{\text {nd }}$ part was the withers height achieved on the basis of $\mathrm{TL}$, $\mathrm{EB}, \mathrm{LMc} / \mathrm{LMt}$ measurements comparison using analysis of variance one-way variance analysis (ANOVA). The $3^{\text {rd }}$ part was devoted to Pearson's correlation coefficient ( $r$ ) analysis. Finally, the $4^{\text {th }}$ part was the regression analysis. During the statistical analysis Prisim ${ }^{\circledR}$ Software was used.

\section{RESULTS}

Accessible osteometric measurements (BL, TL, EB, $\mathrm{Mc} / \mathrm{Mt}, \mathrm{LMc} / \mathrm{LMt}$ ) were used in withers height estimation (Table 1). The mean value of withers height estimated on the basis of LMc is $158.1 \mathrm{~cm}$, subsequently for $L M t=156.3 \mathrm{~cm}$ and $T L=151.7 \mathrm{~cm}$. SD for the above-mentioned values equals: $L M c=11.9$, $\mathrm{LMt}=11.8$ and $\mathrm{TL}=12.2$. The mean value of withers height calculated on the basis of EB is $158.6 \mathrm{~cm}$ and $S D=10.7$. Descriptive statistics results are presented in Table 2. All the parameters are close to normal distribution, therefore the parametric statistical tests were used in further part of statistical analysis. The ANOVA proved the statistical significance $F(3,48)=$ $=9.86 ; p=0.001$. Multiple comparison with Bonferroni correlation use stated the higher withers height results achieved using EB method than TL Kiesewalter's method, TL: $p=0.007$, and similar assumption for LMc Kiesewalter's method results 
Table 2. Descriptive statistics for wither height estimation methods in horses [cm]

\begin{tabular}{lcccc}
\hline Statistics & \multicolumn{3}{c}{ Kiesewalter's method } & EB \\
\cline { 2 - 4 } & LMc & LMt & TL & 158.6 \\
Mean value & 158.1 & 156.3 & 151.7 & 159.2 \\
Median & 157.3 & 153.7 & 148.3 & 10.7 \\
Standard deviation & 11.9 & 11.8 & 12.2 & 137.9 \\
Minimum & 131.7 & 131.5 & 132.8 & 173.6 \\
Maximum & 175.9 & 172.0 & 0.70 & 0.60 \\
K-S test results & 0.57 & 0.68 & 0.704 & 0.868 \\
Statistical significance & 0.907 & 0.747 & & \\
\hline
\end{tabular}

LMc — lateral length of metacarpal bone; LMt — lateral length of metatarsal bone; $\mathrm{TL}$ - total length; EB — internal cranial cavity dimension

Table 3. Pearson's correlation coefficient ( $r$ ) between investigated methods

\begin{tabular}{lcccc}
\hline Method & Kies. Mc & Kies. Mt & Kies. TL & EB \\
\hline Kies. Mc & - & $0.98^{*}$ & $0.83^{*}$ & $0.96^{*}$ \\
Kies. Mt & $0.98^{*}$ & - & $0.80^{*}$ & $0.92^{*}$ \\
Kies. TL & $0.83^{*}$ & $0.80^{*}$ & - & $0.81^{*}$ \\
EB & $0.96^{*}$ & $0.92^{*}$ & $0.81^{*}$ & - \\
\hline
\end{tabular}

${ }^{*} p<0.001$; Kies. Mc - withers height estimation method based on length of metacarpal measurement; Kies. Mt — withers height estimation method based on length of metatarsal measurement; Kies. TL — withers height estimation method based on total length measurement; EB — withers height estimation method based on internal dimension of cranial cavity measurement

Table 4. Regression analysis of chosen withers height estimation methods

\begin{tabular}{lccccc}
\hline Method & $\mathbf{F}(\mathbf{1}, \mathbf{1 5})$ & $\mathbf{P}$ & $\mathbf{R}^{2}$ & Beta & $\mathbf{P}$ \\
\hline Kies. Mc & 156.34 & & 0.907 & 0.955 & $<0.001$ \\
Kies. Mt & 79.89 & $<0.001$ & 0.831 & 0.918 & \\
Kies. TL & 29.34 & & 0.639 & 0.813 & \\
\hline
\end{tabular}

Kies. Mc — withers height estimation method based on length of metacarpal measurement; Kies. Mt — withers height estimation method based on length of metatarsal measurement; Kies. TL — withers height estimation method based on total length measurement

and TL Kiesewalter's method, TL: $p=0.012$. Other differences lacked of statistical significance. The Pearson's correlation coefficient ( $r$ ) analysis between investigated withers height estimation methods is shown in Table 3. The single-sign regression analysis was carried out for 3 Kiesewalter's methods (LMc, LMt and TL) in order to EB withers height estimation method results projection. The regression analysis of the above-mentioned withers height estimation methods proved statistical significance (Table 4).

\section{DISCUSSION}

The withers height estimation belongs to the basic methods used in archaeozoology $[22,26]$. The accessible literature is a source of various methods based on cranial and postcranial skeleton measure- ments, but all of these are estimative in character. The crucial point of these investigations was the $\mathrm{Wy}$ rost and Kucharczyk's mathematical formula comparison to other withers height estimation methods used in horses (Kiesewalter's methods). The mean values of withers height calculated on the basis of the $3^{\text {rd }}$ metacarpal bones measurements (LMc) equals $158.1 \mathrm{~cm}$ and subsequently $156.3 \mathrm{~cm}$ on the basis of the $3^{\text {rd }}$ metatarsal bone (LMt). The mean value of withers height calculated on the basis of EB is $158.6 \mathrm{~cm}$. The value is greater than Kiesewalter's methods results, but SD $=10.7$ for EB based method is lower than Kiesewalter's methods results (LMc = $=11.9$, LMt $=11.8)$. Low SD indicates that the data points tend to be very close to the mean value of parameter. 
Moreover, the Wyrost and Kucharczyk's mathematical formula used in dogs' withers height estimation proved its high accuracy to the known and intravital measured withers height [5]. Similar results brought the investigations carried out in roe deer (Capreolus capreolus) [33]. The modified Wyrost and Kucharczyk's mathematical formula probably gives more exact results in horses, too. The withers height mean value computed on the basis of the skull TL is lower than in other methods $(151.7 \mathrm{~cm} ; S D=12.2)$, and therefore the least exact. Although the lowest mean value and the highest SD calculated for the latter method, the regression analysis proved strong correlation between all 4 investigated wither height estimation methods.

Lack of statistical differences between LMc, LMt and EB together with high square correlation coefficient indicates linear function of the values and allow to state the usage of the EB in withers height estimation.

Additionally, Pearson's correlation coefficient ( $r$ ) indicates the withers height, calculated with modified Wyrost and Kucharczyk's formula (EB) use, is much more comparable to the results achieved with the metapodial bones osteometry (LMc and LMt), than to the withers height calculated on the basis of skull TL (Table 3).

The highest correlation proved the withers height estimated on the $3^{\text {rd }}$ metacarpal bones measurements (LMc) and the EB. Similar significant correlations according to horse withers height, horse crupper height, girth, circumference of the metacarpus, live weight and the greatest length of the autopodium skeletons (manus/pedis skeleton) observed Komosa and Godynicki [18] in intravital and post mortal investigations. Moreover, the horse size coefficient calculated on the basis of the $3^{\text {rd }}$ metacarpal and the $3^{\text {rd }}$ metatarsal bones, together with the proximal phalanges, play the biggest role while assessing the height of a certain animal [19]. Latter assumption is an important proof of strong correlation between the metapodial bones and estimated withers height. The metacarpal bones based withers height and the same value based on EB is also strongly correlated $\left(r=0.96, R^{2}=0.907\right)$, therefore the EB based withers height method is more accurate than the skull TL based methods.

Intact cranial and postcranial horse skeleton remains occur rare, thus the EB measurement possibility seems to be more applicative in archaeozoological practice due to the artifacts conditions $[2,5-8,34]$.
Finally, Vitt methodology (based on BL and metapodial measurements) allows for the range values of withers height estimation. It would not allow for any statistical comparisons, but can confirm the results achieved with other methods. The range of values was lower than the withers height calculated on the basis of other method every time. The BL Vitt's method is the least exact. It seems to be that the neurocranium is more invariable part of the horse skull than the splanchnocranium.

The morphological investigation of horse skull indicates breed variability $[10,20]$. Arabian horses and thoroughbreds skull length values are similar, but Arabians have smaller and lighter head of these 2 breeds [10]. These authors suggest that this assumption is caused by relatively shorter facial length. The internal dimension of cranial cavity, as one of the neurocranium measurements, should be less variable than TL and therefore breed influence independent. The usefulness of presented mathematical formula should be confirmed in various horse breeds.

\section{CONCLUSIONS}

The investigations of withers height values estimated on the basis of internal dimension of the cranial cavity proved high accuracy of modified method. During the statistical analysis, the results achieved using TL and LMc/LMt methods introduced by Kiesewalter (1888) and modified Wyrost's and Kucharczyk's formula, the lack of statistically important differences and strong correlations were stated. The internal dimension of cranial cavity measurement is a valuable tool, which can be used in the height at withers estimations both in archaeozoological and morphological analyses, especially when other methods (craniometry or/and long bones measurements) are not accessible due to the skeletal material preservation status.

\section{ACKNOWLEDGEMENTS}

The research was supported by statutory research and development activity funds assigned to Faculty of Veterinary Medicine, Wroclaw University of Environmental and Life Sciences.

\section{REFERENCES}

1. Alpak H, Mutus R, Onar V (2004) Correlation analysis of the skull and long bone measurements of the dog. Anat Anz, 186: 323-329.

2. Ambros C, Müller HH (1980) Frühgeschichtliche Pferdeskelettfunde aus dem Gebiet der Tschechoslowakei. Archeol Slov Font, 13: 5-182. 
3. Boessneck J (1956) Ein Beitrag zur Errechnung der Widerristhoehe nach Metapodienmasen bei Rindern. Z Tierzücht Züchtungsbiol, 68: 75-90.

4. Całkin VI (1960) Izmienčivost metapodii i jego značenie dlja izučenija krupnogo rogatogo skota drevnosti. Bull Mosk Obšč Ispyt Prir Otd biol, 65: 109-126.

5. Chrószcz A, Janeczek M, Onar V, Pazvant G, Pospieszny N (2007) The shoulder height estimation in dogs based on the internal dimension of cranial cavity using mathematical formula. Anat Histol Embryol, 36: 269-271.

6. Chrzanowska W, Krupska A (2003) Pferdeknochen aus dem frühmittelalterlichen Burgwall vom Mikulčice. In: Polacek L ed. Studien zum Burgwall von Mikulčice V. Archeologicky Ustav CAV, Brno, pp. 151-208.

7. Driesch von den A (1976) A Guide to the measurement of animal bones from archeological sites. Peabody Museum Bulletin, Harvard University, Massachusetts.

8. Driesch von den A, Boessneck J (1956) Kritische Anmerkungen zur Widerristhöhe aus Längenmessen von frühgeschichtlicher Tierknochen. Säugetierkund Mittelung, 22: 325-348.

9. Driesch von den A (1973) Viehhaltung und Jagd auf der Mittelalterlichen Burg Schiedberg bei Sagon in Graübinden. Schrift Rätisch Mus Chur, 16: 3-41.

10. Evans KE, McGreevy PD (2006) Conformation of the equine skull: a morphometric study. Anat Histol Embryol, 35: 221-227.

11. Fock J (1966) Metrische Untersuchungen an Metapodien einiger europäischer Rinderassen. Diss LMU, Münchnen.

12. Godynicki S, Godawa D (1989) Osteometria i związki wysokościowe w kośćcu sarny. Rocz WSR, Poznań, 104: 3-17.

13. Harcourt RA (1974) The dog in prehistoric and Early Britain. J Archeol Sci, 1: 151-216.

14. Howard L (1963) The metrical attributes of two samples of bovine limb bones. J Zool London, 157: 63-74.

15. Hyland A (1990) Equus. The horse in the Roman World. Yale University Press, New Haven, London.

16. Hyland A (2003) The horse in the ancient World. Sutton Publishing Phoenix Mill Thrupp Stroud, Gloucestershire.

17. Janeczek M, Chrószcz A (2011) The occipital area in medieval dogs and the role of occipital dysplasia in dog breeding. Turk J Vet Anim Scien, 35: 453-458.

18. Komosa M, Godynicki S (2003a) Estimation of exterior traits of the horse on the basis of measurements of the skeleton of autopodium. In: Makowiecki D, Abłamowicz R eds. Archeozoologia 21. Instytut Archeologii i Etnologii, PAN, Muzeum Śląskie, Poznań, Katowice, pp. 73-78.

19. Komosa M, Godynicki S (2003b) Craniometrical examination and characteristics of the head of the horse. In: Makowiecki D, Abłamowicz R eds. Archeozoologia 21.
Instytut Archeologii i Etnologii, PAN, Muzeum Śląskie, Poznań, Katowice, pp. 79-87.

20. Komosa M, Moliński K, Godynicki S (2006) The variability of cranial morphology in modern horses. Zool Sci, 23: 289-298.

21. Koundelka F (1886) Verhältnis der Ossa longa zur Skelethőhe bei den Säugetieren. Verhält Naturforsch, 24: 127-153.

22. Lasota-Moskalewska A (2008) Archeozoologia. Ssaki. WUW, Warszawa.

23. Müller HH (1955) Bestimmung der Höhe im Widerrist bei Pferden. Jahrschrift mitteldeutsch Vorgeschicht, 39: 240-244.

24. Onar V, Belli O (2005) Estimation of shoulder height from long bone measurements on dogs unearthed from Van-Yoncatepe early iron age necropolis in Eastern Anatolia. Rev Med Vet, 156: 53-60.

25. Onar V, Belli O, Owen PR (2005) Morphometric examination of red fox (Vulpes vulpes) from Van-Yoncatepe necropolis in Eastern Anatolia. Int J Morphol, 23: 253-260.

26. Reitz JR, Wing ES (2001) Zooarchaeology. Cambridge University Press, Cambridge.

27. Ruff $C B$, Holt BM, Sladek V, Berner M, Murphy Jr. WA, zur Nedden H, Recheis W (2006) Body size, body proportions, and mobility in the Tyrolean "Iceman". J Hum Evol, 51: 91-101.

28. Schramm Z (1967) Kości długie a wysokość w kłębie u kozy. Rocz WSR Poznań, 36: 89-105.

29. Sindell $P$ (2006) Warhorse. Cavalry in ancient warfare. MPG Books, Bodmin Cornwall.

30. Skibniewski M, Kobryń H, Skibniewska E (2007) Wysokość w kłębie bydła domowego średniowiecznej Polski. Medycyna Wet, 63: 369-372.

31. Teichert M (1969) Osteometrische Untersuchungen zur Berechnung der Widerristhöhe bei frühgeschichtlichen Schweinen. Kühn-Arch, 83: 237-292.

32. Teichert M, May E, Hannemann K (1997) Allometrische Aspekte zur Ermittlung der Widerristhöhe beim Schwein auf der Grundlage der Daten von M. Teichert. Anthropozool, 25, 181-191.

33. Wustinger J, Galli J, Rozpędek W (2005) An osteometric study on recent roe deer (capreolus capreolus L., 1758). Folia Morphol, 64: 97-100.

34. Wyrost P, Kucharczyk J (1967) Versuch der Bestimmung der Widerristhöhe des Hundes mittels der inneren Hirnhöhenlänge. Acta Theriol, 9: 105-110.

35. Zedda M, Manca P, Chisu V, Gadu S, Lepore G, Genovese A, Farina V (2006) Ancient pompeian dogs: morphological and morphometric evidence for different canine populations. Anat Histol Embryol, 35: 319-324. 